\title{
THE LATE INTRACARDIAC R WAVE AND THE PRÆCORDIAL PATTERN OF RIGHT VENTRICULAR HYPERTROPHY
}

\author{
BY \\ D. EMSLIE-SMITH \\ From the Department of Medicine, University of St. Andrews \\ Received April 5, 1955
}

There is no generally accepted explanation of the mainly positive initial deflections seen in the right præcordial electrocardiogram in right ventricular hypertrophy. McGregor (1950) found in Fallot's tetralogy that whereas the initial deflections in right præcordial leads were of the rsR' form or rsR's, direct leads from the right ventricular epicardium were $r S$ in type. He suggested that these mainly positive deflections from the right side of the chest arose from the left ventricle as a result of rotation, or from an area near the right atrio-ventricular groove. Carouso et al. (1952) obtained tall, late positive deflections ( $\mathrm{rs}^{\prime}$ ) in direct leads from the epicardium on either side of the right atrio-ventricular groove in five patients with right ventricular hypertrophy. Similar complexes from the same area in normal animals had already been reported (Groedel et al., 1947).

Several workers interested in human intracardiac electrography have noted that although the ventriculogram obtained from the cavities and great vessels of the right heart is usually mainly negative, sometimes a late, mainly positive deflection is obtained. Kossman et al. (1950) found that in normal patients these late intracardiac $R$ waves ( $q R$ or $r s R^{\prime}$ ) were sometimes recorded from the right ventricle, sometimes from the lower part of the right atrium, or from the pulmonary artery just above the pulmonary valve. They found that deflections of this type in the pulmonary artery or right atrium were reversed on movement of the catheter into the right ventricle, and they argued that this implied that the deflections were caused by depolarization of muscle near both the pulmonary and tricuspid orifices, for example, the crista supraventricularis. They suggested that hypertrophy of this muscle might be responsible for the late positive deflections obtained from right præcordial leads in right ventricular hypertrophy.

In patients with right ventricular hypertrophy Kroop et al. (1951) found this rsR' (or rsR's) pattern just above the pulmonary valve, and in the right atrium; they did not obtain it from the right ventricle. It was not recorded from the pulmonary artery in normal hearts. They, too, pointed out its similarity to the pattern found in leads V1 and aVR in right ventricular hypertrophy, and suggested that it might be caused by depolarization of the right ventricular surface. SodiPallares et al. (1951), discussing the late $\mathrm{R}$ sometimes recorded from within the right atrium, suggested that it arose from the late activation of muscle high in the septum, and they stated that in right ventricular hypertrophy these right atrial patterns were like those recorded from the right præcordium.

This paper records the incidence of the late intracardiac $\mathrm{R}$ wave in 50 patients, and correlates its occurrence and amplitude with right ventricular pressure and form of ventricular complex in the conventional electrocardiographic leads V1 and VR.

\section{MATERIAL AND MeTHODS}

During the cardiac catheterization of 50 cases of congenital and acquired heart disease simultaneous records were made of electrocardiographic leads VR and V1, the intracardiac electrogram, 
and intracavity pressure. The technique, using an electrode-tipped catheter was as previously described (Emslie-Smith, 1955). The diagnoses are shown in Table I. None of the patients had cardiac failure at the time of catheterization; the patient with constrictive pericarditis had a normal right ventricular pressure pulse.

TABLE I

INCIDENCE OF LATE INTRACARDIAC R IN 50 CASES

\begin{tabular}{l|c|c}
\hline \multicolumn{1}{c|}{ Diagnosis } & $\begin{array}{c}\text { Number of } \\
\text { cases }\end{array}$ & $\begin{array}{c}\text { Number of cases } \\
\text { with late intra- } \\
\text { cardiac } \mathbf{R}\end{array}$ \\
\hline Mitral stenosis & 22 & 16 \\
\hline Constrictive pericarditis & 1 & 0 \\
\hline $\begin{array}{l}\text { Pulmonary stenosis (including } \\
\text { Fallot's tetralogy) }\end{array}$ & 18 & 10 \\
\hline Patent ductus arteriosus & $\begin{array}{c}2 \\
\text { Ebstein's anomaly }\end{array}$ & 0 \\
\hline $\begin{array}{c}\text { Complex congenital cardiac } \\
\text { lesion not fully diagnosed }\end{array}$ & 1 & 1 \\
\hline TotaL & 6 & 6 \\
\hline
\end{tabular}

The tracings were recorded as a rule during slow withdrawal of the catheter tip from the pulmonary artery to the right atrium. In analysis of the curves, the shape of the ventricular complex in leads V1 and VR, and the site, form, and amplitude $(\mathrm{mV})$ of any late intracardiac $\mathrm{R}$ were noted, and the right ventricular systolic pressure $(\mathrm{mm}$. $\mathrm{Hg}$ ) was measured with reference to the enddiastolic pressure.

\section{RESULTS}

The results are summarized in Tables II and III which contain all the data from which the correlations discussed below were calculated. The frequency of occurrence of late intracardiac $R$ in various sites is shown in Table IV.

\section{Correlation of Late Intracardiac $R$ with Right Ventricular Systolic Pressure and with Other Features of the} Electrocardiogram

The presence or absence of a late intracardiac R (Fig. 1-3) bore no relation to the height of the right ventricular pressure. In 30 cases with such an $R$, the right ventricular systolic pressure varied from 16 to $154 \mathrm{~mm}$. Hg (mean 69) while in 17 cases with no such $\mathrm{R}$ wave the pressures varied from 18 to $136 \mathrm{~mm}$. $\mathrm{Hg}$ (mean 52) (Fig. 4). Again in 19 cases in which the height of the late intracardiac $R$ wave and the right ventricular pressure could both be measured, there was no clearly significant relationship between the two (Fig. 5). The correlation coefficient here was 0.59 , the highest of many correlations encountered during this investigation, and still barely significant.

Analysis of the patterns of initial deflections in leads V1 and VR in cases with and without a late intracardiac $\mathbf{R}$ have shown no difference in distribution of types in the two groups. The value of the ratio $R / S$ in lead V1 showed no statistically significant relation to the right ventricular systolic pressure in either group, nor to the amplitude of the late intracardiac $R$ in cases with such a deflection. The form of VR bore no relationship to the height of the late intracardiac $R$.

Of the 10 cases with right ventricular systolic pressure over $75 \mathrm{~mm}$. $\mathrm{Hg}$ (range 76-154 mm. $\mathrm{Hg}$, mean 101) the form of the intracardiac ventriculogram showing the tallest late $R$ resembled V1 in only one case, and was similar to VR in four cases. 
TABLE II

Data from Cases with Late INTRACARdiac R WAVE

\begin{tabular}{|c|c|c|c|c|c|c|c|c|c|}
\hline \multirow{3}{*}{$\begin{array}{c}\mathrm{RV} \\
\text { systolic } \\
\text { pressure } \\
(\mathrm{mm} . \mathrm{Hg})\end{array}$} & \multicolumn{6}{|c|}{ Late intracardiac $\mathbf{R}$} & \multicolumn{2}{|c|}{$\mathrm{V} 1$} & \multirow{3}{*}{$\begin{array}{l}\text { VR } \\
\text { Form }\end{array}$} \\
\hline & \multirow{2}{*}{$\begin{array}{c}\text { Maxi- } \\
\text { mum } \\
\text { height } \\
(\mathrm{mV})\end{array}$} & \multirow{2}{*}{$\begin{array}{l}\text { Form ventri- } \\
\text { culogram with } \\
\text { maximum late } \\
\text { intracardiac } R\end{array}$} & \multicolumn{4}{|c|}{ Site } & \multirow{2}{*}{$\begin{array}{l}\text { Form } \\
\text { ventricular } \\
\text { complex }\end{array}$} & \multirow{2}{*}{$\frac{S}{R}$} & \\
\hline & & & PA & RV & RA & Elsewhere & & & \\
\hline $\begin{array}{r}16 \\
20 \\
26 \\
32 \\
36 \\
36 \\
36 \\
40 \\
40 \\
42 \\
45 \\
48 \\
50 \\
50 \\
51 \\
53 \\
54 \\
60 \\
60 \\
73 \\
76 \\
80 \\
80 \\
84 \\
88 \\
92 \\
100\end{array}$ & $\begin{array}{l}1.4 \\
2.5 \\
1.2 \\
0.9 \\
4 \cdot 2 \\
2 \cdot 1 \\
1.4 \\
1 \cdot 8 \\
\\
1.4 \\
1.8 \\
2.5 \\
\\
3.3 \\
3.5 \\
2.5 \\
4.1\end{array}$ & 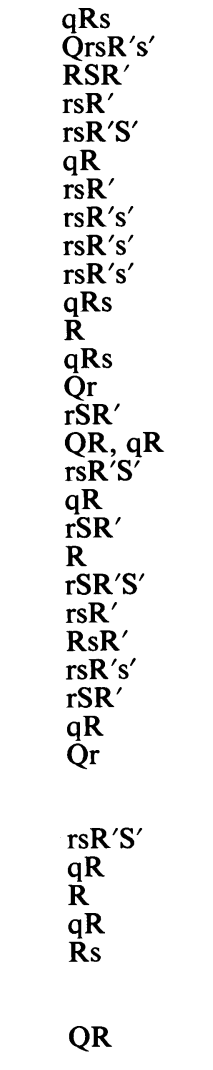 & $\begin{array}{l}+ \\
+ \\
+ \\
+ \\
+ \\
+\end{array}$ & $\begin{array}{l}+ \\
+ \\
+ \\
+ \\
+ \\
+ \\
\\
+ \\
+ \\
+ \\
+ \\
+ \\
+ \\
+ \\
+ \\
+ \\
+ \\
+\end{array}$ & $\begin{array}{l}+ \\
+ \\
+ \\
+ \\
+ \\
+ \\
+ \\
+ \\
+ \\
+ \\
+ \\
+ \\
+ \\
+\end{array}$ & $\begin{array}{c}\text { L.A. and } \\
\begin{array}{c}\text { pulmonary } \\
\text { vein }\end{array} \\
\begin{array}{c}\text { Hepatic } \\
\text { vein }\end{array}\end{array}$ & 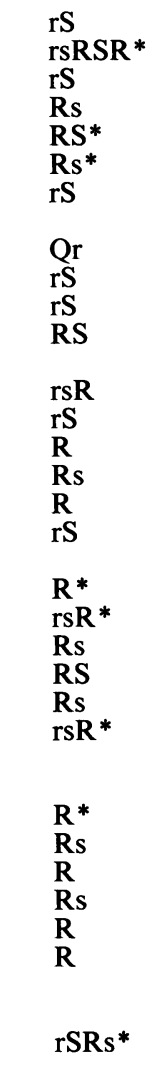 & $\begin{array}{l}3 \cdot 8 \\
2 \cdot 2 \\
0 \cdot 2 \\
1 \cdot 0 \\
0 \cdot 7 \\
4 \cdot 2 \\
\\
\\
4 \cdot 6 \\
3 \cdot 9 \\
1 \cdot 0 \\
\\
0 \\
0 \\
0 \cdot 3 \\
0 \\
1 \cdot 3 \\
0 \\
0 \\
0 \cdot 5 \\
1 \cdot 0 \\
0 \cdot 1\end{array}$ & $\begin{array}{l}\text { Q } \\
\text { rSrsR } \\
\text { Qr } \\
\text { qR } \\
\text { rsRS } \\
\text { Qr } \\
\text { Qr } \\
\text { Qr } \\
\text { Qr } \\
\text { Qr } \\
\text { rS } \\
\text { Qr } \\
\text { Qr } \\
\text { QR } \\
\text { Qr } \\
\text { qR } \\
\text { Qr } \\
\text { qR } \\
\text { Qr } \\
\text { Qr } \\
\text { QR } \\
\text { Qr } \\
\text { Q } \\
\text { QR } \\
\text { rSR } \\
\text { qR }\end{array}$ \\
\hline
\end{tabular}

* Indicates complete right bundle-branch block.

† Only the RA was explored.

Eight of the 50 patients had complete right bundle-branch block: all showed a late intracardiac $R$. It was found that the pattern RSR' or a variant occurred in the initial deflections of the intracardiac lead showing a tall late $\mathrm{R}$ in about half the cases irrespective of the presence or absence of right bundle-branch block. It would therefore appear that an intracardiac lead of the form rsR' is not indicative of bundle-branch block.

No secondary $\mathbf{R}$ waves $\left(\mathbf{R}^{\prime}\right)$ were apparent in V1 in any patient whose intracardiac electrogram showed no late R. Conversely in 29 cases without right bundle-branch block and showing a late intracardiac $\mathbf{R}$ only one showed a secondary $\mathbf{R}$ in lead V1.

\section{Discussion}

It has been suggested that in right ventricular hypertrophy the patterns obtained from the right præcordial, or right unipolar arm, leads are related to intracardiac late positive deflections (Kossman et al., 1950; Kroop et al., 1951; Sodi-Pallares et al., 1951). This study offers no support for 
TABLE III

Data From Cases without Late Intracardiac Wave

\begin{tabular}{|c|c|c|c|}
\hline \multirow{2}{*}{$\begin{array}{c}\text { RV systolic } \\
\text { pressure } \\
(\mathrm{mm} . \mathrm{Hg})\end{array}$} & \multicolumn{2}{|c|}{ V1 } & \multirow{2}{*}{$\frac{\text { VR }}{\text { Form }}$} \\
\hline & $\begin{array}{c}\text { Form } \\
\text { ventricular } \\
\text { complex }\end{array}$ & $\frac{\mathbf{S}}{\mathbf{R}}$ & \\
\hline $\begin{array}{l}18 \\
24 \\
26 \\
30 \\
30 \\
32 \\
32 \\
36 \\
45 \\
50\end{array}$ & $\begin{array}{l}\mathrm{rS} \\
\mathrm{rS} \\
\mathrm{R} \\
\mathrm{R} \\
\mathrm{Rs} \\
\mathrm{RS} \\
\mathrm{rS} \\
\mathrm{Q} \\
\mathrm{rS}\end{array}$ & $\begin{array}{l}1.9 \\
1.9 \\
0 \\
0 \\
0.7 \\
1.0 \\
2 \cdot 2 \\
\frac{3.0}{3 \cdot 0}\end{array}$ & $\begin{array}{l}\mathrm{Qr} \\
\mathrm{Q} \\
\mathrm{rS} \\
\mathrm{Qr} \\
\mathrm{qR} \\
\mathrm{QR} \\
\mathrm{Qr} \\
\mathrm{Qr} \\
\mathrm{Q} \\
\mathrm{Qr}\end{array}$ \\
\hline $\begin{array}{r}52 \\
56 \\
56 \\
62 \\
85 \\
119 \\
136\end{array}$ & $\begin{array}{l}\mathrm{rS} \\
\mathbf{R} \\
\mathrm{rS} \\
\mathbf{R} \\
\mathbf{R} \\
\mathbf{R}\end{array}$ & $\begin{array}{l}6 \cdot 5 \\
0 \\
2 \cdot 6 \\
0 \\
0 \\
0\end{array}$ & $\begin{array}{l}\mathrm{Q} \\
\mathrm{qR} \\
\mathbf{Q} \\
\mathrm{Qr} \\
\mathrm{Qr}\end{array}$ \\
\hline
\end{tabular}

TABLE IV

INCIDENCE OF Late R IN Various INTRaCardiac Sites

\begin{tabular}{cccccccc}
\hline Site & $\begin{array}{c}\text { RV } \\
\text { alone }\end{array}$ & $\begin{array}{c}\text { RA } \\
\text { alone }\end{array}$ & $\begin{array}{c}\text { PA } \\
\text { alone }\end{array}$ & PA+RV & RA+RV & RA+PA & RA+PA+RV \\
\hline Number of cases & 6 & 11 & 1 & 5 & 1 & 2 & 6 \\
\hline
\end{tabular}

Late intracardiac $\mathbf{R}$ recorded from $\mathbf{R A}$ in 20 cases

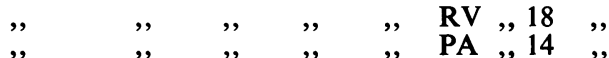

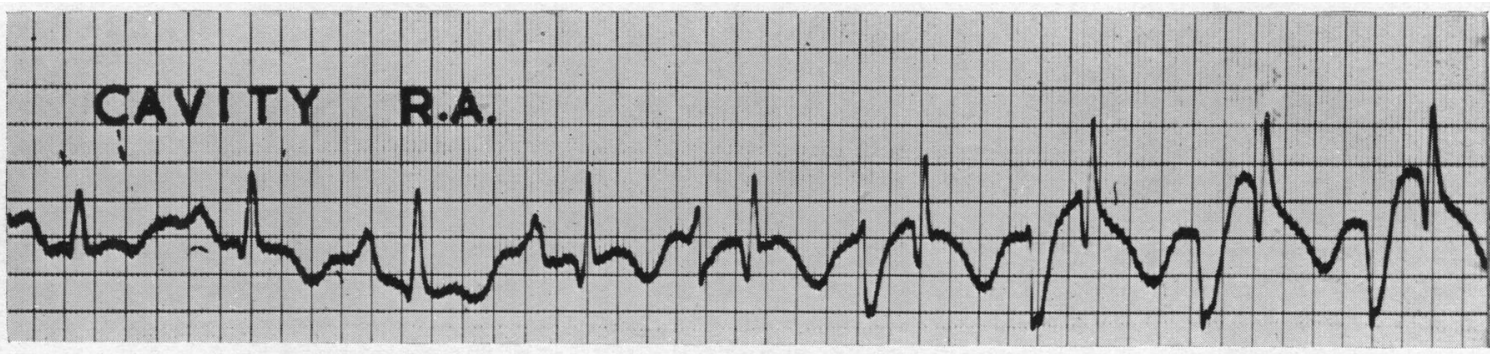

Fig. 1.-Right atrium (low, middle, and high positions). Intracardiac electrogram shows late $\mathbf{R}$ in ventriculogram at all levels.

this hypothesis. A high incidence $(66 \%)$ of late intracardiac $\mathrm{R}$ was found in this series of patients, most of whom had lesions commonly associated with right ventricular hypertrophy. (Its incidence in subjects with normal hearts, or in patients with left ventricular hypertrophy is not known.) No significant relationship was found between the occurrence or height of the late intracardiac $R$ and either the right ventricular systolic pressure or the form of the ventricular complex in leads V1 or VR. G 


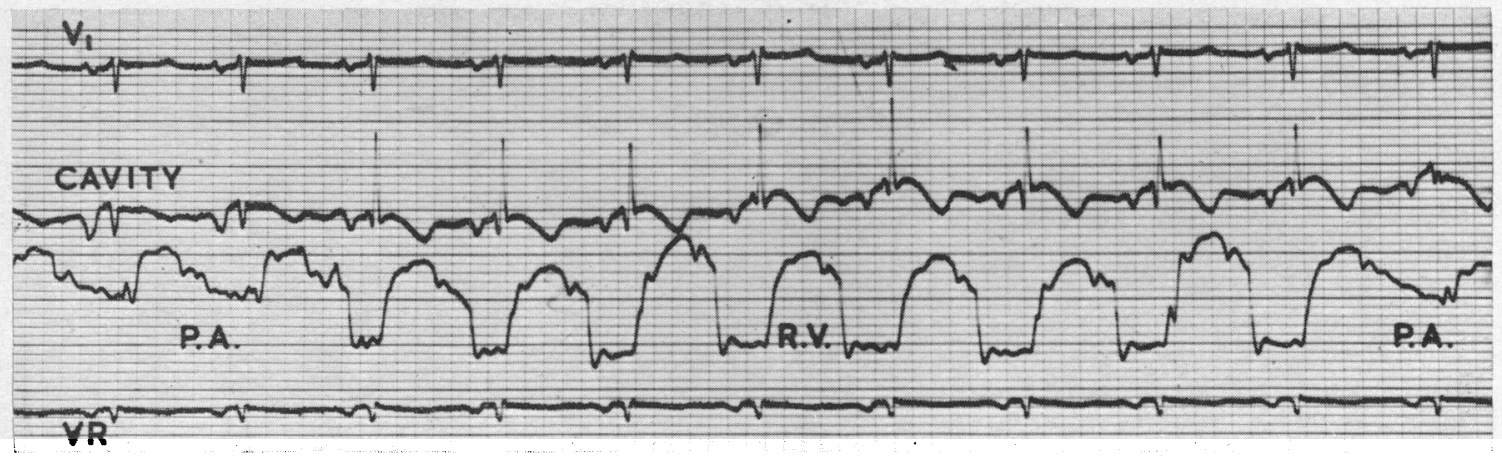

FIG. 2.-Catheter tip moving from PA to RV and back in a case of mitral stenosis. Above downwards: ECG lead V1, intracardiac electrogram, pressure, ECG lead VR. High, late intracardiac R in RV.

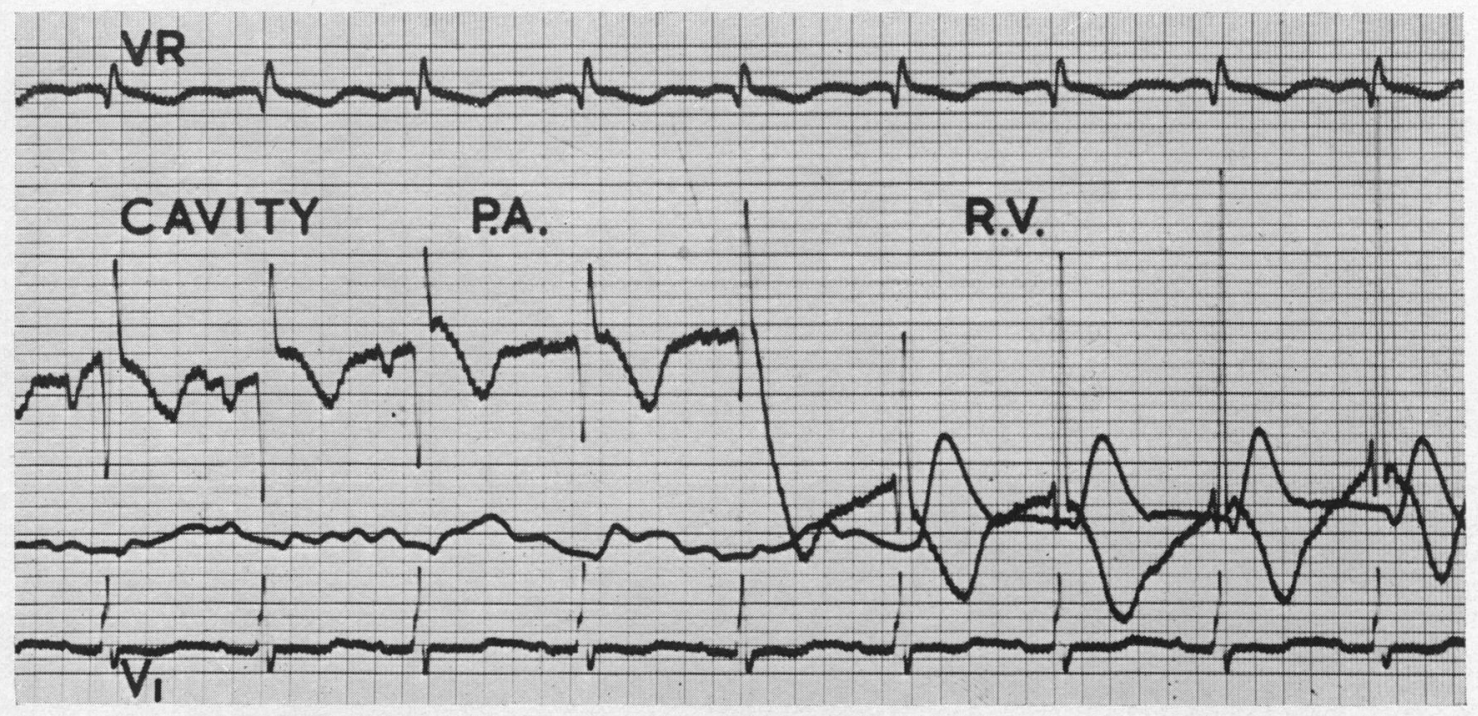

FIG. 3.-Catheter tip moving from PA to RV in a case of pulmonary stenosis. Above downwards: ECG lead VR, intracardiac electrogram, pressure, ECG lead V1. Late intracardiac R in PA and (high voltage) in RV. (The inverted $\mathrm{T}$ of the ventriculogram crosses the upright right ventricular pressure pulse.)

Kossmann et al. (1950) considered that the vector arising from depolarization of the crista supraventricularis in normal hearts produced both the late intracardiac $\mathrm{R}$ and certain deflections sometimes recorded by surface leads: for example, secondary $r$ from the right præcordium. They suggested that hypertrophy of the crista might cause the high, late præcordial $\mathrm{R}$ of right ventricular hypertrophy. It might also be expected to cause a high, late intracardiac R. For this reason the amplitude of the late intracardiac $R$ was measured in this investigation. From the inverse square law it is apparent that the amplitude of a deflection recorded by an exploring electrode is very dependent upon the distance between the electrode and the source of the e.m.f. in the contracting tissue. High amplitude intracardiac deflections may therefore indicate simply that the electrode is very near a portion of contracting muscle; consideration of the method employed here shows that it is not possible to determine within a few millimetres the position of the electrode within the ventricular cavity in its relation to, for example, the crista supraventricularis. 


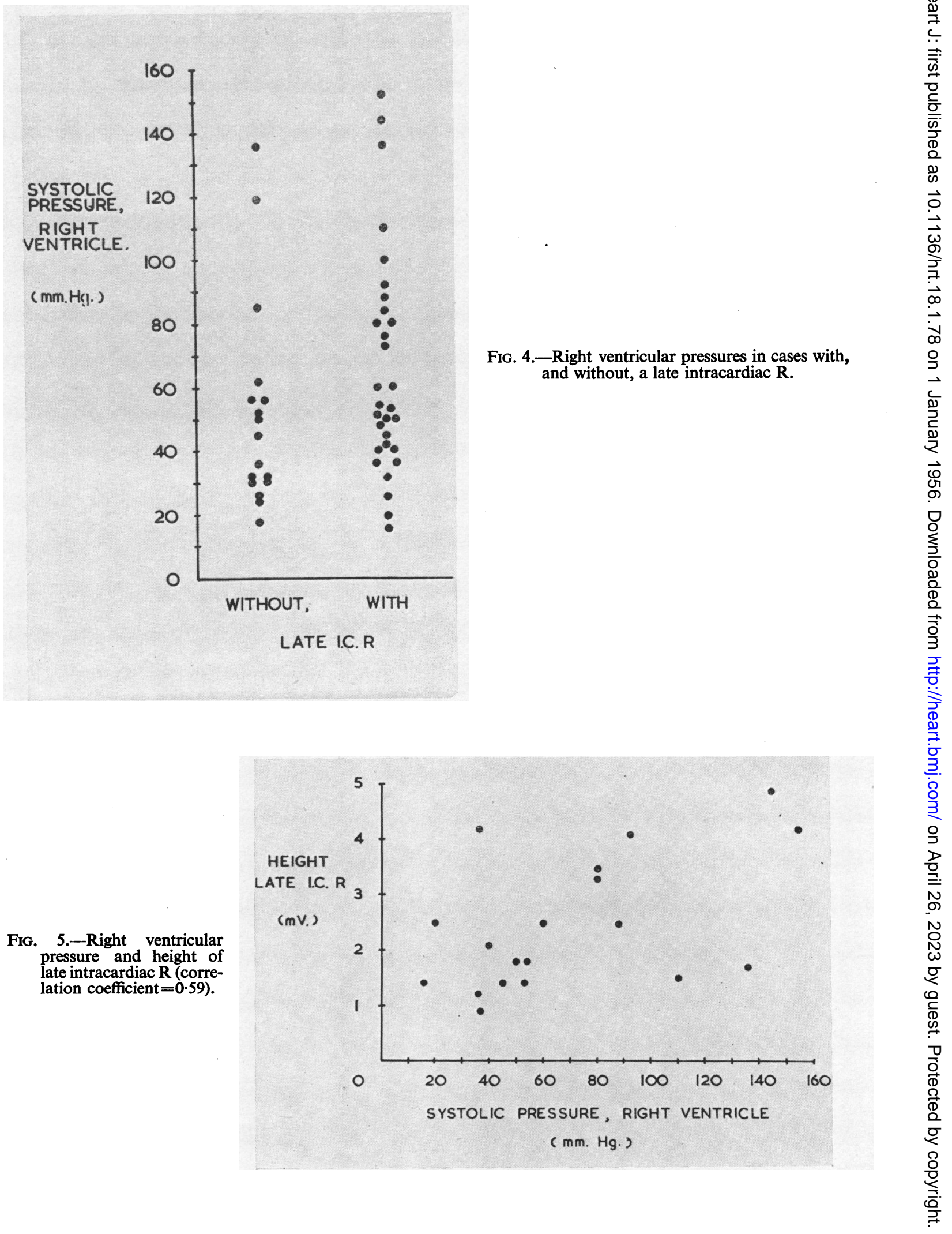


Camerini and Davies (1955) have recently suggested that the secondary $R$ ( $r$ ) which they consider to be a normal finding in some right præcordial leads may be related to the late intracardiac $R$. In this investigation a secondary $\mathrm{R}$ in V1 was not seen in the group that did not show a late intracardiac $R$, but was present in five cases of the group that did show a late intracardiac $R$. Four of these cases showed complete right bundle-branch block, and in three of them the intracardiac ventriculogram with the tallest late $R$ did not show a secondary $R$. However, only V1 was examined, and a præcordial secondary $\mathbf{R}$ might have been commoner in either group had other right præcordial leads been examined.

In cases of right bundle-branch block a late intracardiac $\mathbf{R}$ may be expected from septal depolarization above and below the block (Sodi-Pallares et al., 1948). The removal of the eight cases of right bundle-branch block from this series does not alter the significance of any of the correlations.

\section{SUMMARY}

The intracardiac electrogram has been recorded from 50 patients during cardiac catheterization. A late intracardiac $\mathbf{R}$ was recorded in 33 cases, most commonly from right atrium and right ventricle. No significant relationship appears to exist between the occurrence or amplitude of this $R$ and either the right ventricular systolic pressure or the form of the ventricular complex in leads V1 or VR.

I am grateful to Professor I. G. W. Hill for clinical and laboratory facilities and help in preparation of the manuscript, to Dr. K. G. Lowe for his help with cardiac catheterization, to Dr. W. A. Wilson for statistical evaluation of the data, to the staff of the Professorial Medical Unit and the Radiology Department, Dundee Royal Infirmary, and to the secretarial and technical staff of the Department of Medicine.

\section{REFERENCES}

Camerini, F., and Davies, L. G. (1955). Brit. Heart J., 17, 28

Carouso, G. J., Chevalier, H. A., Latscha, I., Lenègre, J. (1952). Circulation, 5, 48.

Emslie-Smith, D. (1955). Brit. Heart J., 17, 219.

Groedel, F. M., Kisch, B., Borchardt, P. R. (1947). Exper. Med. and Surg., 5, 411.

Kossmann, C. E., Berger, A. R., Rader, B., Brumlik, J., Briller, S. A., Donnelly, J. H. (1950). Circulation, $2,10$.

Kroop, I. G., Steinberg, M. F., Grishman, A. (1951). Amer. Heart J., 41, 891.

Macleod, A. G. (1938). Amer. Heart J., 15, 165.

McGregor, M. (1950). Brit. Heart J., 12, 351.

Sodi-Pallares, D., Rodriguez, M. I., Chait, L. O., Zuckermann, R. (1951). Amer. Heart J., $41,569$.

—, Thomsen, P., Soberon, J. (1948). Amer. Heart J., 36, 1. 